\title{
A mini review on biological potential of 1,3,4-oxadiazole derivatives
}

\author{
Mohammad Asif ${ }^{1, *}$, Abida ${ }^{2}$ \\ ${ }^{\mathbf{1}}$ Associate Professor, ${ }^{\mathbf{2}}$ Assistant Professor, ${ }^{1}$ Dept. of Pharmacy, ${ }^{2}$ Dept. of Pharmaceutical Chemistry, ${ }^{\mathbf{1}}$ Guru Ram Das (PG) Institute of \\ Management and Technology, Dehradun, Uttarakhand, India, ${ }^{2}$ Faculty of Pharmacy, Northern Border University, Rafha, 91911 , PO Box \\ 840, Saudi Arabia
}

*Corresponding Author: Mohammad Asif

Email: aasif321@gmail.com

\begin{abstract}
Among heterocyclic compounds, 1,3,4-oxadiazole has become an important synthons in development of new drugs. Compounds containing 1,3,4-oxadiazole cores have a broad biological activity spectrum, including antibacterial, antifungal, analgesic, anti-inflammatory, antiviral, anticancer, antidepressant, anticonvulsant, and anti-diabetic properties. The ability of 1,3,4-oxadiazole heterocyclic compounds to undergo various chemical reactions has made them important because of their privileged structure, which has an enormous biological potential.
\end{abstract}

Keywords: Heterocyclic compound, 1,3,4-oxadiazoles, Biological activities.

\section{Introduction}

1,3,4-Oxadiazole is a heterocyclic compound containing an oxygen atom and two nitrogen atoms in a five-membered ring. Oxadiazole rings contain two carbon atoms, two nitrogen atoms, and one oxygen atom. Although 1,3,4-oxadiazoles have been known for about 80 years, it is only in the last decade that investigations in this field have<smiles>c1conn1</smiles><smiles>c1ncon1</smiles>

been intensified. It is derived from furan by substitution of two methylene groups with two nitrogen atoms. There are four isomers of oxadiazoles: 1,3,4-oxadiazole, 1,2,4oxadiazole, 1,2,3-oxadiazole and 1,2,5-oxadiazole. However, 1,3,4-oxadiazole and 1,2,4-oxadiazole are better known, and more widely studied by researchers because of their many important chemical and biological properties. ${ }^{1-5}$

\section{1,2,3-oxadiazoles 1,2,4-oxadiazoles 1,2,5-oxadi:izoles 1,3.4-oxadiazoIes}<smiles>c1cnon1</smiles>

anticancer agent. Oxadiazole nucleus is present in antihypertensive drugs such as Zibotentan, nesapidil and antibiotics such as furamizole. ${ }^{6-8}$ GABA-modulating 1,2,4oxadiazole derivatives are known for their anticonvulsant activity. 2,5-Disubstituted 1,3,4-oxadiazoles have also attracted great interest due to their applications in organic light emitting diodes, photoluminescence, polymers and material science. mentioned here. The compounds containing 1,3,4 oxadiazole unit currently used in clinical medicine are: Raltegravir, an antiretroviral drug and Zibotentan, an oxadiazoles in the most diverse areas, for example in drug synthesis, scintillating materials, and the dyestuffs industry. Research is also in progress to explore the various biological<smiles>Cn1c(C(C)(C)NC(=O)c2nnco2)nc(C(=O)NCc2ccc(F)cc2)c(O)c1=O</smiles>
Raltegravir Zibotentan<smiles>COc1nc(C)cnc1NS(=O)(=O)c1cccnc1-c1ccc(-c2nnco2)cc1</smiles><smiles>COc1cc2nc(N3CCN(C(=O)c4nnc(SC)o4)CC3)nc(N)c2cc1OC</smiles> 
<smiles>Nc1nnc(C(Cc2ccc([N+](=O)[O-])o2)c2ccco2)o1</smiles>

\section{Furamizole}

Anticancer and Antimicrobial activity: Some new fluorine containing 1,3,4-oxadiazoles (1a-f), (2a-c) and (3ac) as potential antibacterial and anticancer agents. Most of<smiles>Fc1cc(-c2n[nH]c(=S)o2)c(Cl)cc1Cl</smiles>

(1a-f)<smiles>[B]C1NN=C(c2cc(F)c(Cl)cc2Cl)O1</smiles>

them showed promising antibacterial activity. Also two out of nine compounds showed anticancer activity in the primary anticancer assay. ${ }^{9}$

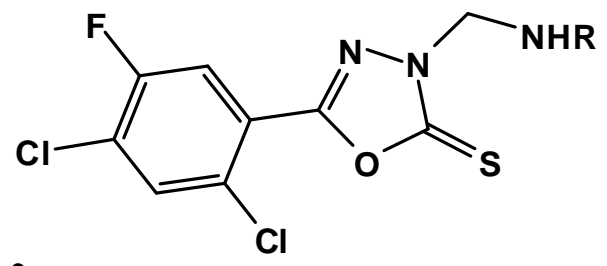

2a-c

2a $\mathrm{R}=$ Morpholino; 2b R=Methyl piperazino; $2 \mathbf{c} \mathrm{R}=$ Piperidino

\section{3(a-c) 3a $\mathrm{R}=\mathrm{CH}_{3} ; \mathbf{3 b R}=\mathrm{C}_{4} \mathrm{H}_{9} 3 \mathbf{c R}=\mathrm{C}_{6} \mathrm{H}_{5} \mathrm{CO}$}

The 3,5-disubstituted-[1,2,4]oxadiazoies (4 and 5) and analogs as activators of caspases and inducers of apoptosis. ${ }^{10}$ In vitro anti-proliferative activity of some novel 5-(2-amino-3-pyridy1)-2-thioxo-3/f-1,3,4-oxadiazole<smiles>Cc1noc(C2=CCCO2)n1</smiles>

$4 \mathrm{~A}=$ heterocycles<smiles>Nc1cc(-c2noc(-c3sccc3Cl)n2)ccc1Cl</smiles>

6 derivatives 6-8. One of the oxadiazoles show'ed cytotoxic activity against the cells of 4 human cell lines. ${ }^{11}$

5<smiles>CN(C)C(=O)SCc1nnc(-c2ccccc2N)o1</smiles><smiles>Cc1nnc(-c2ccccc2N)o1</smiles>

7<smiles>CCOC(=O)SCc1nnc(-c2ccccc2N)o1</smiles>

8

Antimicrobial activity of 1,3,4-oxadiazoles carrying imidazole moiety (9a-1). Most of the tested compounds showed promising antibacterial and antifungal activity. ${ }^{12}$ 
<smiles>[R7]C1([R])OC(Cn2c([N+](=O)[O-])cnc2C)=NN1C(C)=O</smiles>

(9a-l)

$\begin{array}{cc} & \mathrm{R}_{1} \\ \text { 9a } & \mathrm{H} \\ \mathbf{9 b} & \mathrm{H} \\ \mathbf{9 c} & \mathrm{H} \\ \mathbf{9 d} & \mathrm{H} \\ \mathbf{9 e} & \mathrm{H} \\ \mathbf{9 f} & \mathrm{H}\end{array}$

$\mathrm{R}_{2}$

p-Toyl

p-Anisyl

p-Chlorophenyl

p-Bromophenyl

p-nitrophenyl

3,4-methyien-

dioxyphenyl

$\begin{array}{lll} & \mathrm{R}_{1} & \mathrm{R}_{2} \\ \mathbf{9 g} & \mathrm{CH}_{3} & \text { Phenyl } \\ \mathbf{9 h} & \mathrm{CH}_{3} & \text { p-Anisyl } \\ \mathbf{9 i} & \mathrm{CH}_{3} & \text { p-Chlorophenyl } \\ \mathbf{9 j} & \mathrm{CH}_{3} & \text { p-Bromophenyl } \\ \mathbf{9 k} & \mathrm{CH}_{3} & \text { p-Nitrophenyl } \\ \mathbf{9 l} & \mathrm{CH}_{3} & \begin{array}{l}\text { 3,4-methylene- } \\ \text { dioxyphenyl }\end{array}\end{array}$

Anticancer activity of novel 5-(2-hydroxy phenyi)-3-substituted-2,3-clihydro-K3.4-oxadiazo!e-2-thione derivatives (10a1). Some of the compounds produced a good anticancer activity [12a].

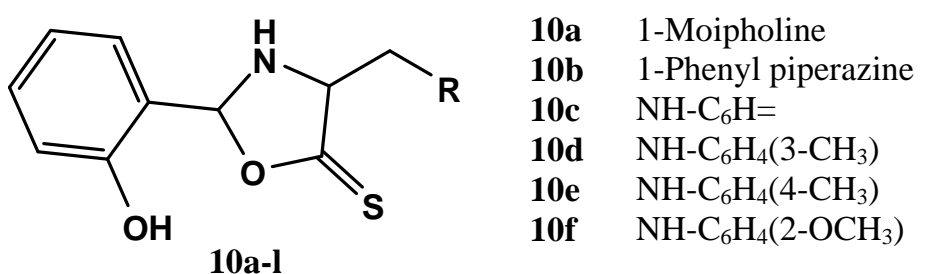

Antibacterial activity of coumarin incorporated 1,3,4oxadiazoles 11. Most of the compounds showed moderate antibacterial activity ${ }^{13}$ and evaluated the antibacterial activity of 5-aryl-2-arylthio-1,3,4-oxdiazoles $12 .{ }^{14}$ The antifungal activity of new 1,3,4-oxidiazolo [3,2-b]-s-triazine-5-ones

$\begin{array}{ll}\mathbf{1 0 g} & \mathrm{NH}-\mathrm{C}_{6} \mathrm{H}_{4}\left(4-\mathrm{OCH}_{3}\right) \\ \mathbf{1 0 h} & \mathrm{NH}-\mathrm{C}_{6} \mathrm{H}_{4}\left(2-\mathrm{OC}_{2} \mathrm{H}_{5}\right) \\ \mathbf{1 0 i} & \mathrm{NH}-\mathrm{C}_{6} \mathrm{H}_{4}(2-\mathrm{C} 1) \\ \mathbf{1 0 j} & \mathrm{NH}-\mathrm{C}_{6} \mathrm{H}_{4}(3-\mathrm{Cl}) \\ \mathbf{1 0 k} & \mathrm{NH}-\mathrm{C}_{6} \mathrm{H}_{4}(4-\mathrm{Cl}) \\ \mathbf{1 0 1} & \mathrm{NH}-\mathrm{C}_{6} \mathrm{H}_{4}(4-\mathrm{Br})\end{array}$

and their thione anaiogoues 13a-c. Antifungal activities of the prepared compounds have been compared with Dithane M-45 against Phytophthara infestans and Collectotricum falcatiun and the results correlated with their structural features. ${ }^{15}$

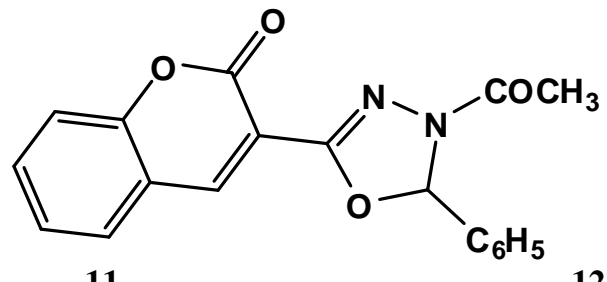

11<smiles>O=S(=O)(OBr)c1nnc([Te])o1</smiles>

12

13aR $=\mathrm{NH} 2,13 \mathrm{bR}=\mathrm{SH}, 13 \mathrm{c} \mathrm{R}=\mathrm{OH}$

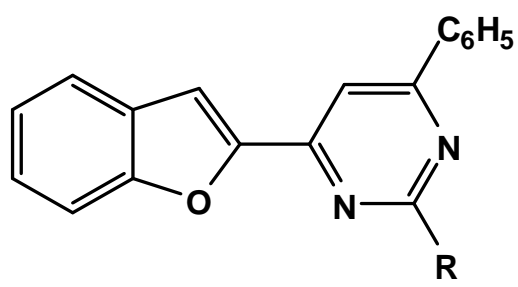

$\mathbf{R}$
Antibacterial activity of pyrazole and 1,3,4-oxadiazole derivatives of 2-phenyl-1,8-napth>ridine compounds 14 and
15 have been tested for their antibacterial activity using streptomycin as a reference compound. ${ }^{16}$<smiles>O=Cc1cn(Cc2ccccc2-c2ccccc2)nc1-c1ccccc1</smiles>

14<smiles>c1ccc(-c2cc3cccnc3nc2-c2ccccc2)cc1</smiles>

15

antimicrobial activity of some new 2-substituted-[1,3,4]oxadiazino $\left[5,6\right.$ 'b] indole 18 . The compounds has shown $\mathrm{H}_{\mathrm{I}^{-}}$ antihistaminic and higher antibacterial activity than the respective standards pheniramine maleate and ampicillin. ${ }^{19}$ 


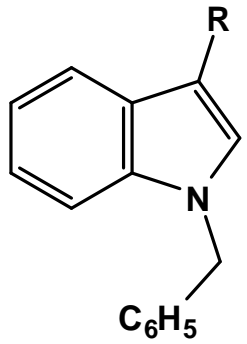

16a $\mathrm{R}=\mathrm{CONHNH}_{2}$, 16b $\mathrm{R}=\mathrm{CHC}_{6} \mathrm{HN}\left(\mathrm{CH}_{3}\right)_{2}-4$<smiles>Cc1ccc2c(c1)C1=NN=C(CS)OC1N2</smiles>

$18 \mathrm{R}^{1}=$ 2-ben2imidazoyl
Some oxadiazoles bearing 2-arylamino-5-mercaptoI,3.4-[hiadiazole niiclei as possible antimicrobial agents. ${ }^{20}$
Antibacterial activities of 1,3,4-oxadiazole derivatives containing 5-methyl isoxazole moiety (19a-e)-(22a-c). ${ }^{21}$
$\mathrm{H}_{3} \mathrm{C}$<smiles>[R7]N([R])Cn1nc(-c2cc(C)on2)oc1=S</smiles>

(19a-e)<smiles>[R]C([R])=NNC(=O)c1cc(C)on1</smiles>

(20a-c)<smiles>[R]c1ccccc1C1NN=C(c2cc(C)on2)O1</smiles>

(21a-c)<smiles>[R7]C1([R7])OC(c2cc(C)on2)=NN1C(C)=O</smiles>

22a

22b

$22 \mathrm{c}$

19a

19b

$19 \mathrm{c}$

19d

19 e

20a

20b

20c

21a

21b

21c
Compounds

(22a-c)

Antibacteriai activity of pyrazole and 1,3,4-oxadiazole derivatives of 2-phenyl-1.8-napthyridine compounds 23 and

$\begin{array}{ll}\mathrm{R}_{1} & \mathrm{R}_{2} \\ \text { Morpholinyl } & \text { Morpholinyl } \\ \mathrm{H} & \mathrm{C}_{6} \mathrm{H}_{5} \\ \mathrm{H} & 4-\mathrm{C}_{1} \mathrm{C}_{6} \mathrm{H}_{4} \\ \mathrm{H} & 4-\mathrm{BrC}_{6} \mathrm{H}_{5} \\ \mathrm{H} & 4-\mathrm{O}_{2} \mathrm{NC}_{6} \mathrm{H}_{4} \\ \mathrm{CH}_{3} & \mathrm{C}_{6} \mathrm{H}_{5} \\ \mathrm{H} & 4-\mathrm{Cl} \mathrm{C}_{6} \mathrm{H}_{4} \\ \mathrm{H} & \mathrm{C}_{6} \mathrm{H}_{5}\end{array}$

4-H

$4-\mathrm{Cl}$

$4-\mathrm{Br}$

$\mathrm{CH}_{3}$

$\mathrm{H}$

$\mathrm{C}_{6} \mathrm{H}_{5}$

$4-\mathrm{Cl} \mathrm{C}_{6} \mathrm{H}_{4}$

$\mathrm{H} \quad \mathrm{C}_{6} \mathrm{H}_{5}$

24 have been tested for their antibacterial activity using streptomycin as a reference compound. ${ }^{22}$<smiles>O=C(c1ccccc1)c1cc2cccnc2nc1-c1ccccc1</smiles>

23

$\mathrm{CHO}$

24

with their parent thioureas. The structural features of the tested compounds have been correlated with their fungicidal activity. ${ }^{23}$ Antimicrobial study of heterocycle substituted Striazoles, 1,3.4-thiadiazoles, oxadiazoles 27 and related heterocycles. ${ }^{24}$ and Fusariurn oxyspoitrrn and the results are compared 


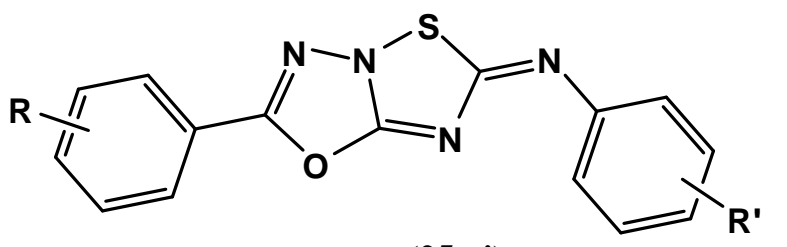

$\begin{array}{llllll} & \mathrm{R}_{1} & \mathrm{R}_{2} & & \mathrm{R}_{1} & \mathrm{R}_{2} \\ \text { 25a } & 2-\mathrm{F} & 2-\mathrm{Cl} & \mathbf{2 5 f} & 3-\mathrm{F} & 4-\mathrm{Cl} \\ \mathbf{2 5 b} & 4-\mathrm{F} & 2-\mathrm{Cl} & \mathbf{2 5 g} & 2-\mathrm{F} & 4-\mathrm{CH}_{3} \\ \mathbf{2 5 c} & 3-\mathrm{F} & 2-\mathrm{Cl} & \mathbf{2 5 h} & 4-\mathrm{F} & 4-\mathrm{CH}_{3} \\ \mathbf{2 5 d} & 2-\mathrm{F} & 4-\mathrm{Cl} & \mathbf{2 5 i} & 3-\mathrm{F} & 4-\mathrm{CH}_{3}\end{array}$

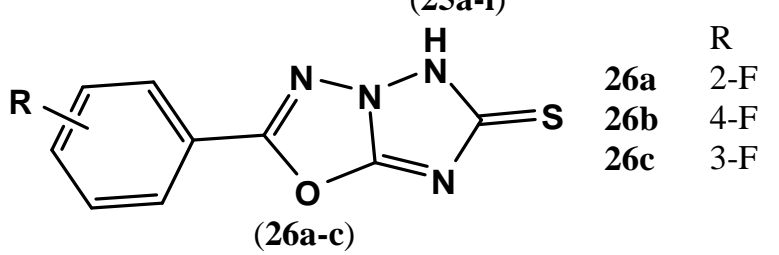

25e $4-\mathrm{F}$

4-Cl<smiles>[X]c1nnc(Nc2ccccc2)o1</smiles>

$27 \mathrm{~A}=$ Heterocycle

Antimicrobial activity of 5-(pyrazol-5-yl)-1,3,4-oxadia2ole-2(3H)-thiones (28a-c) and (29a-c). ${ }^{25}$<smiles>[R]c1c(-c2ccccc2)nn(CCCCC)c1-c1n[nH]c(=S)o1</smiles>

(28a-c)

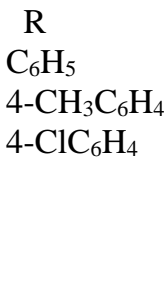<smiles>[R7]c1c(-c2ccccc2)nn(CCCCCCCCCCCCCCCCC)c1C(=O)NN</smiles>

$(29 a-c)$<smiles>[R2]c1nn(CCCCC)c(=N)s1</smiles>

$\mathrm{R}_{1}$

$\mathrm{C}_{6} \mathrm{H}_{5}$

4- $\mathrm{CH}_{3} \mathrm{C}_{6} \mathrm{H}_{4}$ 4- $\mathrm{ClC}_{6} \mathrm{H}_{4}$
$\mathrm{R}_{2}$

$\mathrm{C}_{6} \mathrm{H}_{5}$ $\mathrm{C}_{2} \mathrm{H}_{5} \mathrm{O}_{2} \mathrm{C}$ $\mathrm{CH}_{3} \mathrm{CO}$
The synthesis and antimicrobial activity of some novel oxadiazole, thiadiazole and triazole derivatives. ${ }^{26}$ The chloramine-T-mediated syntliesis of 1,3,4-oxadiazoie along with their antimicrobial activity. Among the compounds tested, few compounds have displayed significant anti fungal activity. ${ }^{27}$ Various rearrangements and dehydration reactions of 1,3,4-oxadiazoles were worked out extensively.
Polyphosphoric acid influenced dehydration of 1-acetyl-2ary!-hydrazine and their rearrangements to afford 2-methyl5-aryl-1,3,4-oxadiazoles $30 . .^{28}$ The synthesis and antimicrobial activity of benzamido phenyl oxadiazole 31 , most of the compounds possess bactericidal and fungcidal activity. $^{29}$

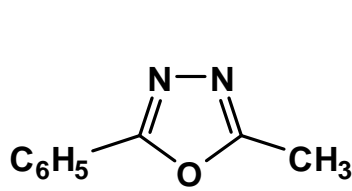

30

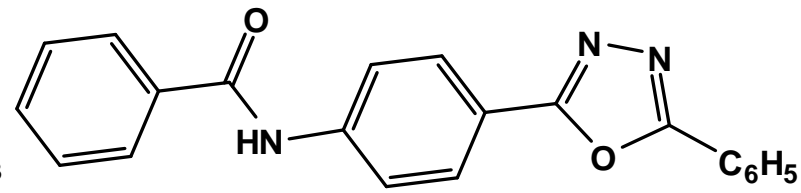

31
Synthesized and evaluated the antimicrobial activities of oxadiazole, 1, 5-disitbstituted-2-mercapto-1, 3, 4-tritiz,ole and 2, 5-disubstitited-2-mercapto-1, 3, 4-thiadiazole derivatives. ${ }^{30}$ Synthesized eight $2-(3,4$ dihydro-3-oxo-2H1,4-benzoxazin-2-yl-methy!)-5-ajkyl/arylthio)-1.3,4oxadiazoles 32 from their respective hydrazides. All the compounds were screened for antimicrobial activity against B. suhtilis, B. polymyxia, E. coli, A, niger. F. oxysporiuin and $P$. grixeofillviuin. ${ }^{31}$ Further, condensation of 3bromoacetyl coumarin and 2 amino-4-phenyl oxadiazole, various oxadiazolyl derivatives 33 showed moderate antimicrobial activity. ${ }^{32}$ A series of 1,3,4-oxadiazoles 34 by the cyclisation of respective hydrazides. They were screened for their antibacterial, antifungal and antirnycobacterial activities. $^{33}$<smiles>[R7]n1ncc(-c2nnc(N[PH]([R14])=[R14])o2)c1C</smiles> 
Mannich bases synthesized from 1,3,4-oxadiazoles were screened for biological activities, 3-(2-isopropyl-1,5dimethyl) phenoxymethyl '4 amino-5-mercapto-1,3.4oxadiazoles 35 were synthesized starting from thymol. Various amino derivatives were obtained by the reaction of formaldeliyde and the oxadiazole-thione. ${ }^{34}$ The synthesis and antibacterial activity of some novel substituted oxadiazoles from p-aryl propiony! hydrazines 36 , All the compounds showed effective anti bacterial activity. ${ }^{35} \mathrm{~A}$ series of 2-(phenyhimino)-5-phenyl-thio/phenyl sulfonyi) methyl-1,3,4-oxadiazole 37. These derivatives were screened for antibacterial activity against E. coil, $K$. pneumonia and S. aureus. ${ }^{36}$

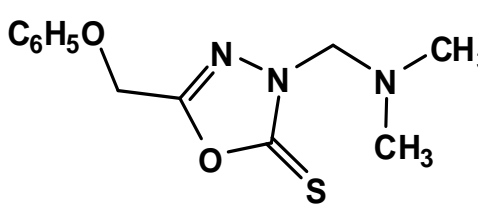

35<smiles>CCCCc1nnc(N)o1</smiles>

36<smiles>c1ccccc1</smiles>

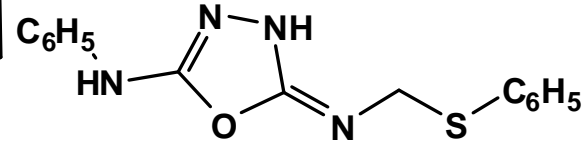

37
The 2-(5-'thioxo-1',3',4-oxadiazol-2'-yl)indoles (38a-c) by the reaction of indole-2-carboxy hydrazides with CS; and $\mathrm{KOH}$. On screening, these compounds showed moderate activity against S. aureus. E. Coli. P. vulgaris and B. Subtilis. ${ }^{37}$<smiles>[R]C=C[SiH3]</smiles>

$(38 \mathrm{a}-\mathrm{c})$

In view of achieving pharmacological compounds of high potency, fusion of 1,3,4-oxadiazoles with various heterocyclic rings by the oxidation cyclisation of the corresponding N-phenyl-N'-(5-aryl-1,3,4 oxadiazol -2-yl) thioureas with pyridine resulting in the synthesis of several 2-ary]-5-phenyl-1,2,4-triazolo(3,2-b)1,2,4 oxadiazol-6thione 39. These compounds were screened in vitro for fungitoxicity against $\mathrm{A}$. niger and $F$. oxysporiiim. ${ }^{38}$
Synthesis of 2-carboxymethyl thio-5-(3 -arylamino sulfophenyl)-1,3,4-oxadiazole 40 , the reaction of 2mercapto-1,3,4-oxadiazole with chloroacetic acid gave the product. The product was screened for antibacterial and antifungal activity against $S$. aureus, E. coli, A. niger and C albicans. Moderate activity was obtained. ${ }^{39}$ Antibacterial and antianioebic activity of substituted amino aryl-1,3,4oxadiazoles 41 . They showed excellent activity. ${ }^{40}$<smiles>S=c1nc2oc(-c3ccccc3)nn2n1-c1ccccc1</smiles>

39<smiles>[R]NS(=O)(=O)c1cccc(-c2nnc(S)o2)c1</smiles>

40<smiles>[R]c1nnc(N)o1</smiles>

41

The antibacterial and antifungal activity of p,p'-bis (2arylamino)-1,3,4-oxadiazol-5'yl-metlioxy sulphones $42 .{ }^{41}$<smiles>[R]c1ccc(Nc2nnc(COc3cccc(S(=O)(=O)c4cccc(OCc5ccc(Nc6nnco6)cc5)c4)c3)o2)cc1</smiles> 
The antibacterial activity of substituted 5-aryl'1,3,4oxadiazoles $43 .^{42}$ The synthesis and antimicrobial activity of $\mathrm{p}, \mathrm{p}^{\mathrm{s}}$-bis diphenyl sulfones $44 .^{43}$

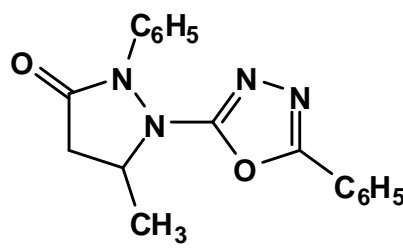

43

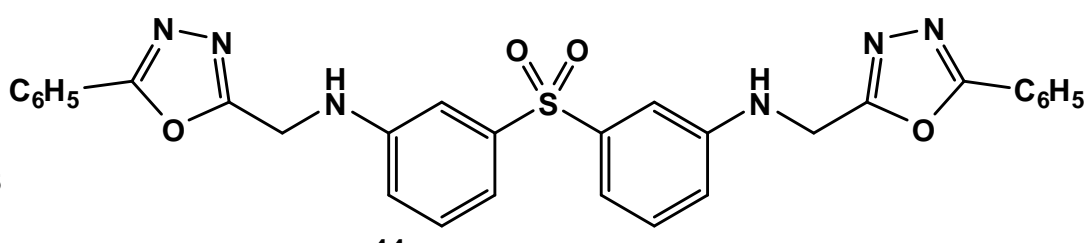

44

The antimicrobial activity of p,p'-bis[[(2arylsuifonamido)-1,3,4-oxadiazol-5--yl)methyl]amino] diphenyl suifones 45 . The synthesized compounds were tested for bactericidal and fungicidal activity, most of them showed moderate activity.<smiles>[R]S(=O)(=O)Nc1nnc(CNc2cccc(S(=O)(=O)c3cccc(NCc4nnc(NS([R])(=O)=O)o4)c3)c2)o1</smiles>

45

The antimicrobial activity of 5-(p-methylbenzoylacetyl)3-phenyl-1,3.4-oxadiazole. The anti tubercular activity of some new 2-substituted thio 5-(4'-pyridyl)-1,3,4- oxadiazoles. Compounds 46 and 47 inhibited the growth of Mycobaaeriim completely at concentration of $20-40 \mathrm{mg} / \mathrm{ml}$ of culture medium.<smiles>Sc1nnc(-c2ccncc2)o1</smiles>

46<smiles>C(=N\c1ccc(Sc2nnc(-c3ccncc3)o2)cc1)\c1ccccc1</smiles>

47
The synthesis and antimicrobial activity of some novel 3,5-disubstituted oxadia2ole-2-thiones.

Anti-inflammatory activity: The synthesis and antiinflammatory activity of Naphathylmethyl oxadiazoies 48 . The tested compounds showed $\$ 5,58 \%$ to $70.13 \%$ inhibition at $100 \mathrm{mg} / \mathrm{kg}$ dose compared to ibuprofen which shows $61.04 \%$ inhibition at $100 \mathrm{mg} / \mathrm{kg}$ dose in carrageenen induced edema in rats. The synthesis and anti-inflammatory activity of substituted 1,3,4-oxadiazole derivatives 49-52.<smiles>[R]c1nnc(C(C)c2ccc(CC(C)c3ccc(Nc4nnc(Cc5ccc6ccccc6c5)o4)cc3)cc2)o1</smiles>

48<smiles>[R]S(=O)(=O)Nc1nnc(C(C)c2ccc(CC(C)C)cc2)o1</smiles><smiles>[R]C(=O)Nc1nnc(C(C)c2ccc(CC(C)C)cc2)o1</smiles>

52 
The synthesis and anti-inflammatory activity of some novel 5-(3,5-substituted hydroxyphenyl)1.3,4-thiazoles, 1,3,4-oxiadiazoles and 1,2,4-triazoles. Synthesized 5-(2hydroxyphenyl)-3-(aryl aminomethyl)1,3,4 -oxadiazole-2$(3 \mathrm{H})$-thiones 53 and screened for their anti-inflammatory activity by paw edema method in rats. The synthesis of a series of 5-(2-anilinophenyl)-1,3,4-oxadiazoles 54-56 and their effective anti-innammatory activity. The spasmolytic and hypotensive activity of 2-(substituted acetyl)amino-5alkyl-1.3,4-oxadiazoles 57.<smiles>Oc1ccccc1-c1nn(CNc2ccccc2)c(=S)o1</smiles>

53<smiles>Cc1ccccc1Nc1ccccc1-c1nnco1</smiles>

54<smiles>[R7]c1cc(-c2nn([R])c(=S)o2)c2ccccc2n1</smiles>

55<smiles>Cc1ccc(C(=O)CC(=O)c2nc(-c3ccccc3)no2)cc1</smiles>

56<smiles>Cc1nnc(NC(=O)CCN(C)C)o1</smiles>

57

Biologically active molecules containing the oxadiazole moiety include the HIV integrase inhibitor ${ }^{44}$ and the antituberculosis agents. ${ }^{45}$ The widespread use of 1,3,4oxadiazoles as a scaffold in medicinal chemistry is evident from the following examples. 2-Amino-1,3,4-oxadiazoles exhibit muscle relaxants (58-60) and show anti-mitotic activity.

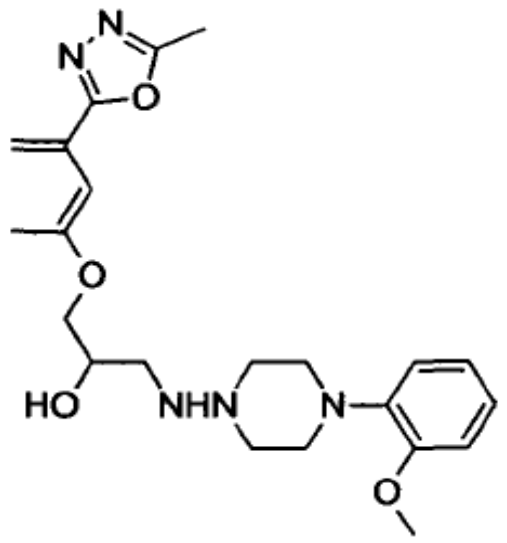

58

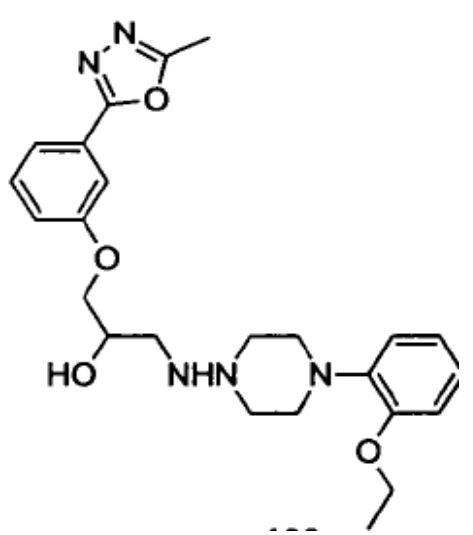

59

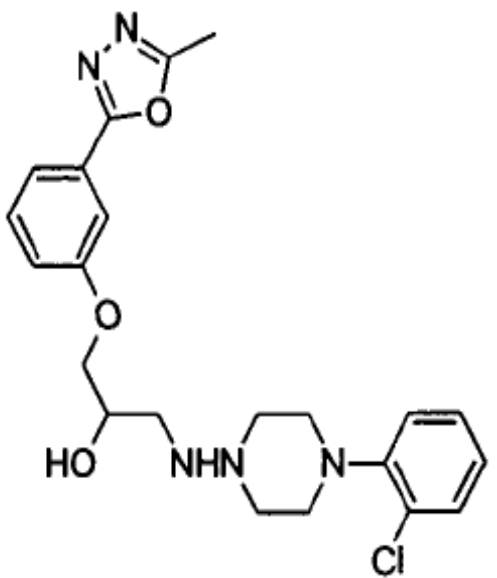

60
The 2,5-Diaryl-1,3,4-oxadiazoles (61) are platelet aggregation inhibitors. 5-Aryl-2-hydroxymethyl-1,3,4- oxadiazole (62) display diuretic, analgesic, antiinflammatory, anticonvulsive, and antiemetic properties.<smiles>c1ccc(-c2nnc(-c3ccccc3)o2)cc1</smiles>

61<smiles>OCc1nnc(-c2ccccc2)o1</smiles> 


\section{References}

1. Tramontini, M.; Angiolini, L.; Ghedini, N. Polymer 1998;29:771

2. Goto, M.; Minoe, T. Jpn. Kokai Tokkyo Koho, JP06 1998;185

3. Mitsch, A.; Wibner, P.; Sattler, I.; Schlitzer, M. Arch Pharm Pharm Med Chem 2001;334:40.

4. Campbell MM: Comprehensive Organic Chemistry Ed. by Sammes PG Pergamon press, 1979;4:1020.

5. Bostrom, J.; Hogner, A.; Llinas, A.; Wellner, E.; Plowright, A.T., J Med Chem 2012;55:1817.

6. Shivi B and Gupta M: J Chem \& Pharm Res 2011;3:137.

7. Farshori N N, Banday M R, Ahmad A, Khan A U and Rauf. Bioorg \& Med Chem Lett, 2010;20:1933.

8. Yathirajan HS, Anil Mayekar N, Narayana B, Sarojini BK, Suchetha Kumari Inter J Chem 2010;2:38.

9. K. Subramanya Bhat, M.S. Karthikeyasi. B. Shivarama HoHa and N, Suchetha Shetty. Indian J Chem 2004;43B:1765.

10. S.X. Cat, H.Z. Zhang, J.D. Kuemmerie. H. Zhang and W.E. Keninitzer U.S. Pat., 2003-U.S. 4030820031238 (2004).

11. H. Liskiewiez, M.W. Kowalska. J. Wietrzyk and A. OpoLski. Indian J Clseni 4 2B (II):2 846 (2003).

12. Priya V Frank and Balakrishna Kalluraya Indian J. Heterocycl. Chem., 44B: 1456 (2005). 6a. A.S.Aboraia, H.M.R Rahman, N.M. Mahfouz and A.EL. Gendy Biorg-Med Chem 2006;14(4):1236.

13. M.A. Bhat, S.A. Khan and N. Siddiqui. Indian J Heteroycl Chein, 2005;14:271.

14. Sandeep Jain, Neelam fain and Pvadeep Mishra. Indian J Heterocycl Chein 2005;14:359.

15. D.V. Singh, A.R. Mishra and Ram Mishra. Indian J Heterocycl Chem 2005;14:289.

16. K. Mogilaiah and S, Sakram. Indian J Heterocycl Chem 2004;13:289.

17. A.H. Farghaly, Abdel - Rahman. J Chin Chem Soc 2004;51(1);147.

18. K. Mogilaiah, K. Srinivas and G. Rama Sudhakar. Indian J Chem 2004;43B:2014.

19. M. Ajiiha, K. Rajnarayana and M. Sangarapani Pharmazie, 2002;57(12):796.

20. Smitha Nair, S.P. Garg and Pramila Sah. Indian J Heterocycl Cheni 2002;12:09.

21. Xin-ping.Hui, Chang-Hu chu and Zi-yi Zhang. Indian J Ciieiii 2002;41B:2176.

22. K. Mogilaiah, D. Srinivas and R. Babu Rao. Indian J Cheni 2001;40B:43.

23. Harendra Singh, Manoj Kumar Srivastva, Brij Kishore Singh, Sanjciy Kumar Singh and Garima Dubey. Indian J Chem 40B: $159(200 !)$.

24. A.H. Dhirnan and K.N. Wadodkar. Indian J Chem 2001;40B:636

25. A.S. Shawali, M.A. Abdallah and M.E.M. Zayed Zeltschrift Fiier. Natriirdorscliung, 2000;6:55.

26. R.N. Herbert and A.L. Hannah U.S.PaL, 98;1832 22 (2000)

27. S.P. Singh, Rajesh Naithani, Hitesh Batra, Om Prakash and Dipti S harm a. Indian J Chem 1998;8:103.

28. A.V. Karnik and G. K. Rajesh. Indian J Cheni 1996;6:91.

29. Joshi, Naliesh, A. Budothra and Parekh J, Indian Cheni Soc 1996;73:700

30. B.S, Vashi, D.S. Mehta and V.H. Shah. Indian J. Chem 35 B 1996;(2):111.

31. Y. Fayamma, M. Sorangapam and V.M. Reddy. Indian J Heterocycl Chem 1996;6;91.

32. Sushanta, K. Sahu and M. Amresh. Indian J Chem 1996;6:103.

33. R.P. Kapoor and H. Batra. Indian J HeterocycL Chem 1997;7:1.

34. B. Kalluraya, R. Chimbathar and P. Gunaya. Indian J Chem 1996;6:103.
35. Andiotra, Charanjit sigh and T.C. Langer. Indian J Pharm Sci 1996;48;192.

36. Shafi, S. Syed and T.R. Ramakrishna. Indian J Chem 1995;51:135.

37. V.N. Sanur and N. Sreeni vasulu. Indian J Heterocycl 1995;4:203.

38. V.F. Mishra, H. Singh and J.P. Mishra. Indian J Pharm Sci 1994;56:1.

39. V.H. Shah and V.R. Parik. Indian J Pharm Sci 1992;54:98.

40. P.L. Kachroo, R. Gupta and S.C. Gupta. Nat Acad Sci Left 1991;13:125.

41. P. S. Upadhyay and R.N, Vanisadodia. Indian J Pharm Sci 1992;54:1.

42. Begium Tahina, Hussain and A. Shaheen. Pak J Sci, 1989;32(if):722

43. M.H, Meshkatalsadat, M.A. Shahsafi and H. Parekh. J Fust Chemists 1989;61(3):114.

44. Rai NP,- Narayanaswamy VK, Shashikanth S, Arunachalam PN, Euro J Med Chem 44, 4522 (2009)

45. Cooper K., Steele J., EP329357, Chem. Abstr. 112, 1990, 76957.

How to cite this article: Asif $M$, Abida. A mini review on biological potential of 1,3,4-oxadiazole derivatives. Int J Pharm Chem Anal 2018;5(4):179187. 